\title{
Body, spirit and gender in Maria Komornicka's poetry
}

\author{
Katarzyna Lisowska \\ kalisowska@wp.pl
}

\begin{abstract}
This paper concerns three significant concepts in Maria Komornicka's writings: body, spirit and gender. The first two are closely related to each other, thus initial paragraphs are devoted to them both. On the basis of these reflections, I draw some conclusion about the image of gender created by the poet. The notion of gender is analysed in terms of Young Poland discourse of gender and from the perspective of modern methodologies: feminist criticism as well as gender and queer studies. This paper aims at encouraging the reader to reinterpret M. Komornicka's output with contemporary awareness.
\end{abstract}

Keywords: androgyny, anthropology, body, decadence movement, spirit, expressionism, evolutionism, cultural construct, convention, gender, scientism, identity.

Maria Komornicka's writings are often reinterpreted nowadays. One can find there not only Young Poland tendencies, but also postmodern dilemmas. Taking into account both of these aspects I would like to analyze three key factors, namely body, soul and gender.

The poet was born in 1876 of a noble family. Her mother, neé Anna Dunin-Wąsowicz, as a descendent of a legendary magnus procurato, Piotr Włast (Baranowska 1981, p. 69). M. Komornicka was provided with an excellent education. She was taught in a manor house in Grabowo, and then in Warsaw where she was supervised by Piotr Chmielewski. One of her stories was first published in "Gazeta Warszawska" ["Warsaw Gazette"], and two years later "Szkice" ["Sketches"] (Podraza-Kwiatkowska 1996, p. 5), an anthology of her prose, was published. Those achievements could have foretold great literary success. However, M. Komornicka's life did not turn out according to expectations.

Izabela Filipiak treats her biography as a key to understanding the works of the author. Therefore, I. Filipiak, in her book entitled Obszar odmienności. Rzecz o Marii Komornickiej [The area of difference. About Maria Komornicka], tried to explain M. Komornicka's biography in terms of its symbolic meaning. In order not to repeat the work of this author, I would like to mention just a few facts which might have had a great influence on $\mathrm{M}$. 
Komornicka's literary output. M. Komornicka was rebellious and in her childhood she went against the constraints imposed on her due to the tradition of a noble family. Unfortunately, her despotic father, Augustyn Komornicki, tried to control his daughter's life (Baranowska 1981, p. 70). Nevertheless, when he sent her to the University of Cambridge (Janion 1996, p. 257), she, against his will, came back after just a few months disappointed with its patriarchal atmosphere. Soon after that, A. Komornicki died due to a heart disease. M. Komornicka moved to Warsaw where she became a left-wing activist. In 1895, together with Cezary Jellenta and Wacław Nałkowski, she published a collection Forpoczty, of which a part was her series Liryka wierszem i prozq [Lyric in verses and prose], and in 1905 she participated in a revolutionary movement (Podraza-Kwiatkowska 1996, p. 6-7).

She married Jan Lemański, a poet. However they were not a happy couple - within three years they decided to separate (Baranowska 1981, p. 75). Then she was in a relationship with Gustaw Walewski. Unfortunately, shortly after that, he died from pneumonia (PodrazaKwiatkowska 1996, p. 7). Both these relationships might have exerted an impact on M. Komornicka's perception of gender.

The poet travelled a lot. She lived in Paris for some time. And there, in 1904, she suffered her first breakdown. Three years later, in Poznań in the hotel Bazar she experienced a transformation - she burnt her dresses, pulled out her teeth and started to use masculine forms, calling herself per P. Włast (she used this pseudonym to sign reviews in "Chimera". This behaviour was regarded as a manifestation of a mental disorder. As a result, $\mathrm{M}$. Komornicka, against her will, was treated in different psychiatric hospitals till the outbreak of World War I. After that, she stopped publishing her writings. She came to Grabowo only in 1914, where she was taken under the protection of her brother. Over a period of ten years, she wrote poems which were included in a manuscript entitled Ksiega poezcji idyllicznej [The book of idyllic poetry] which was published posthumously. Forgotten by her contemporaries, M. Komornicka observed the development of Polish literature until her death in 1949.

Despite the fact that M. Komornicka's publishing activity did not last very long, only a few years, her output is significant, literary critics were impressed by the foreword to Szkice [Sketches], where she postulated a departure from realism in prose. This anthology is also an expression of freedom-seeking and interest in women's psychology. Published in 1900 Baśnie. Psalmodie [Fairy Tale. Psalmody] contributed to the Young Poland atmosphere therefore it was considered as "a type of epic moderne." The most prestigious achievement of the poet was cooperation with "Chimera", which published her writings and reviews. In 1905, the magazine published the novel Biesy [Demons], which is an example of confession prose 
and is an expression of the author's interests in psychoanalysis (Podraza-Kwiatkowska 1996, p. 70, 76 i 78).

Nowadays, while rereading these writings, one can see not only strong interdependencies with the atmosphere of the period but also precursory tendencies in respect of our own times. The author participated in the discussion concerning humanity at the turn of the century. In those times, people came back to metaphysical reflection over the individual seen as a mystery. Modernists pondered also on opposing concepts of science and religion. The basic idea was the relation between body and soul since the author devoted herself to this problem.

One can say that for M. Komornicka, and for other modernists, the physical aspect of life was a negative one, but still an undeniable one (Boniecki 1998, p. 26). This aversion towards physicality stemmed probably from reluctance about the scientific viewpoint (Boniecki 1998, p. 70). Besides, the poet saw mortality and ugliness in the body. But at the same time, she knew that the body was the foundation of her awareness. Ambivalent opinions on physicality can be found in the sources used by the author.

The "I"- speaking refers to evolutionism when it describes itself as a part of the whole humanity ("I am the child of the earth! I am the creation of the moment!/ With my being my dying started/ On the relics of those who lived before") (Krzyk [Scream], p. 159]) ${ }^{1}$ or a member of a family ("this clan inside me came to be the most precise formula, to most characteristic crystallization of a type, to accuracy and epitome of the symbol") (Biesy [Demons], p. 359). The body induces disgust ("I was delivered from a bloody mother's womb! [...]/ She caressed me in wounds born -/ Formless, disgusting solid!”) (Krzyk [Scream], p. 159), and mortality makes it weak ("Cold death is present in my every vein") (Nazajutrz [The following day], p. 217), therefore it evokes sadistic feelings ("[...] I lash my face the-only-one - I soak up its paleness and blush, its humility and madness" (Miłość [Love], p. 198). Physiological representation (“And last waves from my veins come [...]/ And still new beats me to the heart/ And submerges them in this sacrificial blood -/ to wring them in the hands' scale as a rag") (Ból fatalny [Fatal Pain], p. 287); ("The albatross flies exhausted/ The wound is bleeding") (Duma [Proud], p. 285), probably inspired by scientism, it is used not only to show the inferiority of matter, but also connects M. Komornicka's writings with early expressionism, rebellious against tragic human existence.

\footnotetext{
${ }^{1}$ All quotes are from (if not stated differently) M. Komornicka 1996, and are marked in the text: title (if not understood form the context) page.
} 
What is more, physical love is a sin against the spiritual nature of a human being ("It is a sin that I love you and a sin that/ you could embrace me") (Hotd [Tribute], p. 183). Although M. Komornicka may be impressed by the masculine body ("indescribable charm of tanned face - sweet threat of purple lips and steel-blue eyes”!) (Miłość [Love], p. 197); ("Cheerful beauty of some sons of earth liberates my admiration and madness") (Biesy [Demons], p. 348), she denies there being a spiritual element. The woman wants to move a man to another level of existence (Podraza-Kwiatkowska 1996, p. 30). It is about spiritualization done radically ("I want to torture myself in you - moan from the deepest abyss, from this precipice of poverty, where the soul, satisfied and full, seeks its shelter. I want to wake up a spirit in you - you who manifested in me a body") (Miłość [Love], p. 198).

The conflict between matter and soul concerns everyone. The poet's dream was gnostic, romantic "angelizing" the body and subjecting it to the developing soul (Boniecki 1998, p. 68- 69). According to Edward Boniecki no earlier than in The book of idyllic poetry M. Komornicka underlies the necessity of unification of both elements of human nature (Boniecki 1998, p. 108). However, it seems that the thought of that unification appeared at a slightly earlier stage of Maria's writing. She mentioned this in the poem entitled Pod wpływem "Szału” Podkowińskiego [Under the impression of Podkowiński's "Frenzy"] in Forpoczty: "perfect soul and body fusion", p. 76. The text Vici expresses dreams of androgyny ("Your body I wanted. Your body [...]/ and my body is made of flesh/ And proud, leaning on your coffin lid", p. 238). In this way, the poet, inspired by evolutionism and neognosis, can be interpreted within metaphysical anthropology which tries to show the whole human being (Stala 1994, p. 27), and her individuality can be interpreted as a characteristic reaction modernism towards the disintegration of "I" (Boniecki 1998, p. 12).

One of the basic assumptions of M. Komornicka's anthropology, concerning the problem of the identity of a human being, was also recognition of human nature as a mystery. The author did not only acknowledge that but also desired to discover the mystery of her own soul. "Desire of self-knowledge" (Biesy [Demons], p. 339) made her conduct experiments. The poem Kaprys [Caprice] (p. 231-233) tells about peculiar plays with personality. "I" speaking takes different masks of nakedness ("The mask of nakedness my spirit wears", p. 231). Perhaps it is about adopting an exhibitionistic pose which is to hide the truth about the individual. The lyric subject marks up the devaluation of symbols at the turn of the century ("The mask of virtues - unprudish was made for them", p. 231); (Zealous heart - is to hide the art of irony", p. 232), which is used to deceive the entourage ("So long I led you into the forest/ Overwise, skeptical brothers", p. 232). However, this act causes tragic results, that is 
“self-knowledge's vague order", p. 232. "I" - speaking loses the ability to tell truth from falsity ("Where is the pretence? Where is the reality? I being tormented by the threat of madness/ Stray in the Tower of Babel"). Owing to this, each act is perceived in a two-fold light ("In my every wince there is truth and falsehood", p. 233). Her misery is based on the fact that she is not able to clearly judge her situation.

Certainly, a lyric subject cannot understand its acts as a reality or pretence („In my naked dress maybe there is falsehood/ This nakedness is maybe a leotard", p. 233 [writer's emphasis - K.L]. Thus, the play turned into clownish comedy ("[...] unconsciously I play in a comedy", p. 233, "Tragic foolery is my infirm being", p. 233), and the soul's image was completely blurred ("Strange chimera as a soul”, p. 233). The existence of lyric subject, dreaming of perfect distribution of masks, turned into absurd ("And here it is - the peak of absurd", p. 233).

A more effective method to tame the soul than experimenting seems to be examining its mystery. The poet accepts this challenge in the poem entitled Pokusa [Temptation], p. 278. Self-consciousness is seen as a struggle with intriguing evil ("I am attracted by the sphinx's bad face -/ I am attracted by the fiery-black depth -/ Its unrevealed secret”, p. 278), which is a key to gain knowledge as it makes one conscious ("Upon quagmire of sharp grass/ My legs clean and naked - strapped - ", p. 278).

The most detailed representation striving for self-knowledge is M. Komornicka's novel Biesy [Demons] which is included in the confession prose. In accordance with the modernists' cult of the individual, the author-narrator describes striving for the analysis of her inner self. Once again she refers to sin. "Will to do evil", considered as powerful, comes back (p. 336). However, in the long term, this fascination with evil turns out to be harmful as well ("[...] then horrified, I notice that the soil where I put the seeds of evil changed their nature", p. 336). The attempt to see oneself from the outside, according to other people, is done in vain as the narrator in her judgments concerning herself finds proof that she is different from others, p. 341-342. Other symbols of self-knowledge are also faulty (Podraza-Kwiatkowska 1996, p. 17). Staring into the mirror is not a key to establish "even one ultimate impression", p. 343, and creating doubles (“On the street there were walking my living models”, p. 344) and all this leads to "infinite BOREDOM", p. 344. A kind of hint is to refer to evolutionism which treats a human being as a part of the development of whole humanity ("This clan was narrowed down to the most terse formula in me", p. 359). Nevertheless, relying on a family requires "clear self-knowledge of our anti-vitality", p. 359 and "CONSCIOUS DEATH", p. 360. 
Solving the mystery can happen only after denying all masks, as a soul wants to ,get ITSELF on the day of birth, to discover its prototype”, p. 352. The mystery of Spirit turns out to be not only impenetrable but also terrifying ("[...] inscrutable and sinister countenance of my Spirit", p. 344), and the confrontation with it is unbearable for a human being ("My earthly sight, my brain did not stand the power of that ghastly abyss", p. 344). Therefore, one may conclude that spirituality is considered as something superior and hardly ever reveals to an individual the sphere where independence increases the impression of the mystery of one's personality.

However, one can notice that for M. Komornicka, most important is the concept of gender, which she related to culture in a two-fold manner. Above all, thanks to the observation of the whole world she has the firm conclusion that the right to be in such a sphere is attributed only to men. During her visit to Great Britain, she wrote: "We, the women, have the stigma of exclusion from the workshops of life [...]. We all suffer from the lack of experience" (Janion 1996, p. 258). Nevertheless, the poet does not want to struggle for emancipation of women, whose situation she despised. She wanted to live as a liberated individual. Therefore, some researches think that the men's existence is a model worth copying (Podraza-Kwiatkowska, p. 13).

The aim is to change the feminine paradigm of existence, which makes the woman unconscious of nature and burdens her with numerous negative myths (Schahadat 2000, p. 260), to the masculine paradigm of existence. However, this type of change would not give complete freedom. E. Boniecki recalls described by Johann Jacob Bachofen and Erich Fromm categories of "matriarchal and patriarchal complex". The first of them consists of affirmation, freedom and equality but also lack of possibility to create individuality and intellect. "The patriarchal complex" allows that and at the same time it is about suppression and inequality. If the poet, aspiring to achieve complete development, had adopted that model, she would have acknowledged its hierarchy discriminating against women (Boniecki 1998, p. 44-45). It turned out, that women do not have access to creative life.

The only solution is the creation of a higher form of being, functioning outside physical divisions. M. Komornicka projected several models of ideal existence. Firstly, it is, rooted in the modernist literature, a dream of androgyny. She describes it in the poem Vici, which can be understood as a vision of fusion of masculinity and femininity ("So you are submissive to me - so you are kneeling before me/ Gold idol [...]! / I wanted your soul. Your body $[\ldots] /$ And my word has already been made flesh", p. 238). The poet wrote also that "the mysterious solidarity of genders creates new for us the proportion of the sum of common 
energy, making new harmony" (Z księgi madrości tymczasowej [Glosy]/ From the Book of temporary wisdom [Vices],p. 266). Then, it was about fusing both aspects of human existence and thanks to this creating a new third gender.

The second method is to "angelize" ("Because You, the man, have future In yourself!/ Each of your fibres asks for a transformation!”) (Nauka węża [The science of snake], p. 407) or to go back to childhood. This notion can be found in the poem Pragnienie [Desire], in which the lyrical subject wants to search "the transformation in the sea", p. 297. Thanks to that, she refers to the symbolical meaning of water associated with fertility and life. Submerging in water can be understood as a return to the embryonic state.

Both of these concepts can be interpreted as a universal project of liberation of both genders. The position of man is better only seemingly. It has, however, the access to cultural conventions, "wardrobe an infinite number of disguises" (Boniecki 1998, p. 140), but M. Komornicka is not afraid to take something out of this "wardrobe". She introduces into her poem masculine "I" - speaking, which, as in the poem Caprice, uses different masks which are rooted in the general imagination. The poet understands gender as a cultural construct independent forms which create the identity of an individual - of men and of women. The reflection of this identity and its dependence on external factors enables readers to interpret Komornicka's poetry within gender studies. However, this approach does not exhaust the problem.

If culture proposes only external forms of identity, then one may conclude that clothes determine gender and behavior (Filipiak 2000, p. 135). This is the impression evoked by the poem Panie I ja [Ladies and I], ("Finally, there is the moment desired -/ Baleen tightens halfchildlike bosoms/ of ladies and me/ We started to look for the »Ideal«/ Examine charm of kissing, trysts and madness") (Komornicka 1981, p. 85). The sphere most vulnerable to shape is the body, which contemporary feminists "of gender difference" treat as a resultant of multiple influences: economic, political, sexual ${ }^{2}$. The control over them is "a means to preserve the identity and manifestation of it to others (Rosner 2006, p. 42). The lack of composure disintegrates personality. Thus, described in the poem Strzyż [Haircut] "patriarchal ceremony" of cutting hair leads to the loss of masculine subject ("I tapped my fingers $[\ldots] /$ As that who does not trust/ in one's own »Ego«/ and is extremely surprised") (Strzyż [Haircut], p. 381). One has to undertake traditional formulas determining gender

\footnotetext{
${ }^{2}$ The feminists of gender 'difference' are of the opinion that the body is the foundation of understanding mental and social existence of women. There representatives of this philosophy are: Luce Irigaray, Helene Cixous, Gayatri Spivak i Monique Wittig. see. E. Hyży 2003, p. 94-95.
} 
(Filipiak 2000, p. 135), which includes mainly external attributes of masculinity and femininity.

Both women and men are influenced by the culture, so taking the place of another gender does not liberate. Hence, the poet aims at gaining an independent identity, neutralizing bodily and social differences. This vision is created in a poem mixing male and female subjects ("I walk as if I(he) was drunk/ of bright emptiness of withered garden [...]/ One day in miraculous arms of an angel -/ And alone (she) again [...]") (Nazajutrz [The following $d a y$ ], p. 215 [emphasis mine - K.L.]). According to I. Filipiak, transforming into a male subject allowed the poet to speak about fantasies attributed to men (Filipiak 2000, p. 124), as adopting another model enables one to use a new language.

M. Komornicka announces performative understanding of gender, which, according to Judith Butler ${ }^{3}$, is about quoting words, gestures and desires attributed to men and women by the discourse (Hyży 2003, p. 163-165). It is worth noticing that in the press debut, the poet used a masculine perspective in publishing stories, whose narrator was a cynic (Filipiak 2006, p. 9-10). Questioning the existence of solid identities and postulating their movement (Skucha 2005, p. 560) and also thinking about gender "difference” (Burzyńska, Markowski 2007, p. 458) makes M. Komornicka's writing close to modern deliberation concerning Queer Theory ${ }^{4}$.

In conclusion, we have to ask about the legitimacy of interpreting the poet's output within Queer Theory. According to Judith Butler, "I" is created only in the discourse constructive performance up to the mark of gestures, words and desires (Hyży 2003, p. 164 and 168). M. Komornicka lacks a stable identity, which would condition her conduct. It seems that, in a way sensing the concept expressed by the author of Uwiktani w pleć [Gender Trouble], M. Komornicka finds her freedom in "opposition towards forced repetition of traditionally recommended acts" (Hyży 2003, p. 161), which is based on the rejection of behaviour attributed to women and quoting norms restricted to men, with lack of acceptance of a binary division.

Associating "valour" with "masculinity" stems from language convention ("manly character, that is valour, is gained only through manly experience, that is experience of valour") (Z księgi madrości tymczasowej [Glosy]/ From the Book of temporary wisdom [Vices], p. 269). The subject of the poems does not feel good in any convention, so in M.

\footnotetext{
${ }^{3}$ J. Butler uses "gender".

${ }^{4}$ Until now the most important attempt of application of the Queer Theory to M. Komornicka's writings is the above-mentioned essay by I. Filipiak.
} 
Komornicka's text one will find both chauvinistic criticism of women ("Even the most elegant and proud woman - there is kind procurement, servile hastiness, which lights up her lower status" (Z księgi madrości tymczasowej [Glosy]/ From the Book of temporary wisdom [Vices], p. 268), and admiration for significance of patriarchy together with sadness caused by exclusion from his world ("What for as a cheerful child I climbed on the Hill/ Where are the living statues and their commander, god-Patriarch/ By powerful sorcery called my heart to happiness and triumph [...]/ When suddenly, someone from the entourage crossed my way -/ and I understood their silence meaning that I can go no further") (Dziwny sen [Strange dream], p. 378-79). Differentiations are not clear, thus the patriarchal system is the subject to criticism, as for example in the story "About father and daughter" from the cycle Baśnie Psalmodie [Fairy Tales. Psalmodies].

However, the poet notices danger hidden in carefree play with conventions. She voices that in a poem Kaprys [Caprice]. M. Komornicka, sharing the belief in freedom with modernists, aims at ultimate liberation, which is understood as identity based on internal harmony: "Harmony! Inner parts' alliance in the name of the complete entirety, and vigilance of the one idea over prosperity of factors, which only stable increase may cause permanent significant intensification of entirety" (Z księgi madrości tymczasowej [Glosy]/ From the Book of temporary wisdom [Vices], p. 259). One may agree with I. Filipiak that the author wanted to see her "I" as "holistic and indivisible" (Filipiak 2006, p. 93-94), considering herself not as a representative of a particular gender, but as a member of the whole humanity ("Rejoice, People! Rejoice!/ That we are and that we are PEOPLE! [...]/ In our every part equally harmonious developed Star [...]/ HUMAN BEING as the image of GOD/ Father, Son and Spirit”) (Ludźmi jesteśmy [We are people], p. 391).

Aiming at integrity should consider also aspects of sexuality. Queer theories emphasize mainly sexual differences. M. Komornicka's poetry was often considered as expression of "inclinations to excesses" and "indefinitness and instability in terms of erotism" (Kralkowska-Gątkowska 1993, p. 92). According to I. Filipiak, the reason for transformation, which was done by the author, may be "regain of sexuality" (Filipiak 2006, p. 94). But what is sexuality about? The researcher, interpreting the main character in the novel entitled Halszka, refers to the concept of virginity proposed by Marion Woodman. According to her, this state suspends division between body and soul, feminine and masculine symbolicism (Filipiak 2006, p. 241).

That would correspond, as noted by literary scholars (M. Janion, J. Sosnowski) to desire to return to times of childhood, as a shelter from the banal and allowing a vision of 
reality following the saints' example (Filipiak 2006, p. 92). If one takes into consideration reluctance towards physical love ("You cannot love: you can only sin") (Z księgi mqdrości tymczasowej [Glosy]/ From the Book of temporary wisdom [Vices], p. 270), the poet's attitude towards sexuality turns out to be more complex. It can be stated - as I. Filipiak claimed - that the author wanted to shape this aspect of life once again, maybe, near to that of childlike purity, but its shape was not yet determined.

I have tried to prove that M. Komornicka's writings can be looked at from a variety of angles. It turns out that modern methodologies create very interesting perspectives as they investigate distinctiveness, that is feminine studies together with gender and queer theories. From this point of view, the most significant aspect is the author's considerations of gender, and as a result - her attitude towards body and spirituality. However, it has to be borne in mind that this reading does not exhaust the complexity of M. Komornicka's output.

\section{Sources}

Bajda J. (ed.) (2007), Poezja drugiej połowy XIX wieku (pozytywizm-Młoda Polska).

Antologia, Agencja Wydawnicza a linea, Wrocław.

Komornicka M. (1996), Utwory poetyckie wierszem i prozq, Podraza-Kwiatkowska M. (ed.), Wydawnictwo Literackie, Kraków.

\section{Bibliography}

Baranowska A. (ed.) (1981), Kraj modernistycznego cierpienia, Państwowy Instytut Wydawniczy, Warszawa.

Boniecki E. (1998), Modernistyczny dramat ciała. Maria Komornicka, IBL, Warszawa.

Burzyńska A., Markowski M.P. (2007), Teorie literatury XX wieku. Podręcznik, Wydawnictwo Znak, Kraków.

Filipiak I. (2000), W. $+M .=M . W$, [in:] Ritz G., Binswanger Ch., Scheide C. (eds.), Nowa świadomość ptci $w$ modernizmie. Studia spod znaku gender $w$ kulturze polskiej i rosyjskiej $u$ schyłku stulecia, Towarzystwo Autorów i Wydawców Prac Naukowych "Universitas", Kraków.

Filipiak I. (2006), Obszary odmienności. Rzecz o Marii Komornickiej, Słowo/ Obraz/ Terytorium, Gdańsk.

Hyży E. (2003), Kobieta, ciało, tożsamość. Teorie podmiotu w filozofii feministycznej końca XX wieku, Wydawnictwo Universitas, Kraków. 
Janion M. (1996), Kobiety i duch inności, Wydawnictwo Sic!, Warszawa.

Komornicka M. (1981), Panie i ja, [in:] Baranowska A. (ed.), Kraj modernistycznego cierpienia, Państwowy Instytut Wydawniczy, Warszawa.

Kralkowska-Gątkowska K. (1993), Dziwne miasto Eropolis. Obszary i funkcje erotyki w tekstach Marii Komornickiej, [in:] Piętkowa R. (ed.), Eros, psyche, seks. Materiały z konferencji „Język i erotyka”, zorganizowanej przez Koło Naukowe Językoznawców Uniwersytetu Ślaskiego, Towarzystwo Zachęty Kultury, Katowice.

Wyka K., Hutnikiewicz A., M. Puchalska (eds.) (1973), Literatura okresu Młodej Polski, volume 3, Wydawnictwo Literackie, Warszawa.

Piętkowa R. (ed.) (1993), Eros, psyche, seks. Materiaty z konferencji „Język i erotyka”, zorganizowanej przez Koło Naukowe Językoznawców Uniwersytetu Ślaskiego, Towarzystwo Zachęty Kultury, Katowice.

Podraza- Kwiatkowska (1996), Wstęp, [in:] Komornicka M., Utwory poetyckie wierszem i prozq, oprac. M. Podraza-Kwiatkowska, Wydawnictwo Literackie, Kraków.

Podraza-Kwiatkowska M. (1985), Somnambulicy, dekadenci, herosi. Studia i eseje o literaturze Młodej Polski, Wydawnictwo Literackie, Kraków.

Ritz G., Binswanger Ch., Scheide C. (eds.) (2000), Nowa świadomość ptci w modernizmie. Studia spod znaku gender w kulturze polskiej i rosyjskiej u schytku stulecia, Wyd. Universitas, Kraków.

Rosner K. (2006), Narracja, tożsamość i czas, Wyd. Universitas, Kraków.

Schahadat S. (2000), Szalone kobiety, nerwowi mężczyźni: histeria $i<<$ gender $>>n a$ przełomie wieków, [in:] Ritz G., Binswanger Ch., Scheide C. (eds.), Nowa świadomość płci w modernizmie. Studia spod znaku gender $w$ kulturze polskiej i rosyjskiej u schytku stulecia, Kraków.

Skucha M. (2005), Gender, queer, literatura, "Ruch Literacki” 6.

Stala M. (1994), Pejzaż człowieka. Młodopolskie myśli i wyobrażenia o duszy, duchu i ciele, Wydawnictwo Baran i Suszczyński, Kraków.

Wyka K., Markiewicz H., Wyczańska I. (eds) (1973), Obraz literatury polskiej XIX i XX wieku, Volume 1-5, Wydawnictwo Literackie, Warszawa. 